\title{
Trombiculiasis in domestic goats and humans in the state of Maranhão, Brazil
}

\author{
Trombiculíase em caprinos domésticos e humanos no Estado do Maranhão, Brasil \\ João Luiz Horácio Faccini ${ }^{1}$; Ana Clara Gomes Santos ${ }^{2}$ Sandra Batista Santos ${ }^{3}$; Fernando de Castro Jacinavicius ${ }^{4}$; \\ Ricardo Bassini-Silva5; Darci Moraes Barros-Battesti ${ }^{5 *}$

\begin{abstract}
${ }^{1}$ Departamento de Parasitologia Animal, Universidade Federal Rural do Rio de Janeiro - UFRRJ, Seropédica, RJ, Brasil
${ }^{2}$ Departamento de Patologia, Unidade de Medicina Veterinária, Universidade Estadual do Maranhão - UEMA, São Luís, MA, Brasil

${ }^{3}$ Laboratório de Bacterioses dos Animais Domésticos, Universidade Federal Rural de Pernambuco - UFRPE, Recife, PE, Brasil

${ }^{4}$ Laboratório Especial de Coleçóes Zoológicas, Instituto Butantan, São Paulo, SP, Brasil

${ }^{5}$ Laboratório de Parasitologia, Instituto Butantan, São Paulo, SP, Brasil
\end{abstract}

Received July 28, 2016

Accepted November 16, 2016

\begin{abstract}
Trombiculiasis is an infestation caused by larval mites (chiggers) of the family Trombiculidae. Here, we provide the first report on parasitism by the chigger species Eutrombicula alfreddugesi (Oudemans) and Eutrombicula batatas (Linnaeus) in goats and humans on farms in the state of Maranhão, northeastern Brazil. Severe itching and dermatitis caused by the chiggers' bites were seen. From a total of 779 examined goats, 214 of them showed clinical signs of infestation, as well as family members of three farms of the region. Most of the cases occurred during the rainy season, from March to September.
\end{abstract}

Keywords: Chiggers, parasitism, northeastern Brazil.

\section{Resumo}

Trombiculíase é uma infestação causada por larvas de ácaros da família Trombiculidae. Nós reportamos pela primeira vez parasitismo por ácaros das espécies Eutrombicula alfreddugesi (Oudemans) and Eutrombicula batatas (Linnaeus) em cabras e humanos em fazendas no estado do Maranhão, nordeste do Brasil. Foram observadas dermatite e coceiras severas causadas pelas picadas de trombiculídeos. De um total de 779 cabras examinadas, 214 delas apresentaram sinais clínicos de infestaçôes, assim como membros de três famílias de fazendeiros da regiāo. A maioria dos casos ocorreu durante a estação chuvosa, de março a setembro.

Palavras-chave: Trombiculídeos, parasitismo, nordeste do Brasil.

\section{Introduction}

Trombiculiasis is caused by parasitism by larval mites (chiggers) of the family Trombiculidae (SHATROV, 2000). The larvae feed on their hosts by using chelicerae to inject lytic enzymes into the upper layers of the skin and, subsequently, to ingest digested cells. After feeding and detachment, the mites molt to free-living nymphs and then to adults (JONES, 1950; SHATROV, 2000). Infestation by chigger mites causes severe itching as well as transmission of diseases like scrub typhus, which is caused by the intracellular parasite Orientia tsutsugamushi in southeastern Asia and the southwestern Pacific region (TAKAHASHI et al., 2004; CHOI et al., 2007). Likewise, in Spain, Fernández-Soto et al.

*Corresponding author: Darci Moraes Barros-Battesti. Laboratório de Parasitologia, Instituto Butantan, Av. Vital Brasil, 1500, CEP 05503-900, São Paulo, SP, Brasil. e-mail: darci.battesti@butantan.gov.br
(2001) detected the bacterium Anaplasma phagocytophilum (cited as Ehrlichia phagocytophila) in larvae of Neotrombicula autumnalis (Shaw), before their contact with their hosts, thus suggesting that transovarian transmission of the pathogen occurs. Borrelia burgdorferi sensu lato was detected by Kampen et al. (2004) in chiggers collected in Germany. Literak et al. (2008) found B. garinii and B. valaisiana in chiggers in the Czech Republic. Chigger mites are usually nonspecific to their hosts and have been reported in several groups of vertebrate hosts worldwide. The species Eutrombicula alfreddugesi (Oudemans) can parasitize birds, lizards and mammals, as well as humans. Species of this genus are distributed in the tropical, subtropical and temperate regions of the Western hemisphere (LOOMIS \& WRENN, 1984; WRENN \& LOOMIS, 1984). Although, heavy infestation with Eutrombicula spp. may cause weakness, anorexia and even death 
among young chickens (CARNEIRO, 1952; BAKER, 1999) and young ostriches and house sparrows (ORNELAS-ALMEIDA et al., 2007), no pathogens transmitted by chiggers to domestic animals and humans have been reported in the New World.

In Brazil, the relationship between parasitic mites and goats is still poorly understood. Knowledge about this relationship is limited to data on three mite species that are included in other families: Psoroptes ovis (Hering) (sensu WALL \& KOLBE, 2006), Raillietia caprae Quintero, Bassols and Acevedo, and Demodex caprae Railliet, which all have economic importance. The first two of these species have been correlated with subclinical otitis (FACCINI \& RIBEIRO, 2008) and the last with skin lesions that cause damage to leather (PADILHA, 1982). On the other hand, chiggers have not been reported in Brazilian goats yet, although Apolonia tigipioensis Torres \& Braga has been diagnosed in chickens and humans, and Eutrombicula batatas (Linnaeus) in chickens, rodents and horses (EWING, 1925; CARNEIRO, 1952; GUIMARÁES et al., 2001). Therefore, the aim of the present study was to provide the first report on occurrences of trombiculiasis in goats on smallholder farms and also in humans in the state of Maranhão, northeastern Brazil.

\section{Materials and Methods}

The farms investigated are located in the municipalities of Bacurituba (2o 42' 21" S; 44o 44' 16" W), Pinheiro (2o 31' 17" S; 45 04' 57” W), Sáo Bento (2o 41' 45” S; 440 49' 17” W) and São João Batista (02 57’ 19” S; 440 48’ 25” W). These farms are located in a microregion of the state of Maranhão known as "Baixada Maranhense", which is close to the edge of the Amazon forest in Brazil (Figures 1 and 2). The data for this study were gathered between October 2003 and September 2005. After a clinical examination on the 779 goats, chiggers $(n=12)$ were collected from 3 out of 214 infested animals or with clinical parasitism signal. The mites were removed by means of superficial skin scraping and were then preserved in $70 \%$ alcohol. A portion of the mites collected was sent to the Butantan Institute for identification. The specimens

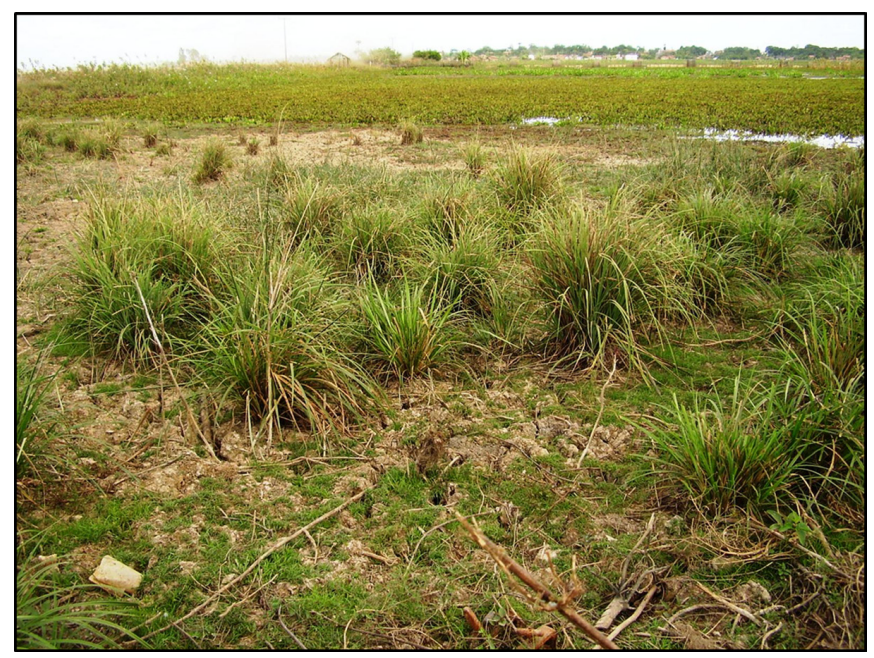

Figure 1. Goat-rearing location with view of the Amazon forest in the background. were mounted in Hoyer's medium as described by Walter $\&$ Krantz (2009) and were identified in accordance with the data of Wolfenbarger (1952) and Brennan \& Goff (1977). In order to illustrate the mites, morphological examination was performed and drawings were made using a Leica DFC 500 digital camera coupled to a Leica DM4000B optical microscope. Extended focal range images were composed using the Leica Application Suite version 2.5.0. The figures were prepared using Adobe Photoshop v. 13.0 and Inkscape V. 2.

The chigger mites were compared with types and other material deposited in the USNM Smithsonian Acari Collection, which is housed at the Systematic Entomology Laboratory (BARC-USDA-ARS), Beltsville, MD, USA.

\section{Results}

A total of 779 goats (345 in the first year and 434 in the second year) on smallholder farms were examined for the presence of chigger lesions. The prevalence of clinical parasitism was as follows: 26 out of 345 animals examined in the first year (7.5\%) and 188 out of 434 animals examined in the second year (43.3\%) were positive. Infestations in the goats were recognized as clusters of orange to red granular material surrounded by areas of pustular dermatitis and intense pruritus. The lesions consisted of alopecia, scaly erythematous skin and papules scattered across the body. Most of the goats were highly infested and larval mites were found at the base of their ears, dewlap, dorsal region from neck to groin, abdomen, udder and limbs. In addition, clinical signs of trombiculiasis were also diagnosed on farmers and their families in the municipalities of Bacurituba (parents and six children), Pinheiro (parents and five children, between eight months and 13 years old) and São Bento (father and two children, seven and 14 years old) (Figures 2 and 3 ). The clinical signs consisted basically of areas of papular dermatitis located on the feet, legs, knees, hands, fingers, arms, face and scalp. The lesions were circular, focal and multifocal, of sizes ranging from 2 to $4 \mathrm{~cm}$ in diameter. Scratching the papules because of the intense pruritus resulted in large inflamed areas of the skin.

Eight voucher specimens identified as E. batatas and four as E. alfreddugesi were deposited in the Acari Collection of the Butantan Institute, São Paulo, Brazil, under the accession numbers IBSP 11068 and IBSP 10547, respectively. The species were compared with the type Trombicula brasiliensis Ewing, 1925, which was collected in Manaus, Amazonas, Brazil (syn. junior of E. batatas), and with material from $E$. alfreddugesi and E. batatas that is deposited in the USNM. The farmers were also examined clinically, but no skin scrapings were performed.

The diferencial diagnosis of the two chiggers is as following:

The ventral palpal tibia setae are branched in E. batatas (Figure 4A) while they are nude in E. alfreddugesi (Figure 5A); the shape and the punctuation of dorsal scutum differ in both species (Figures 4B and 5B), being more punctuated in E. alfreddugesi; the two long specialized setae (mastitibiala) on tibia of the Leg III are present only in E. batatas (Figure 4F); there are three long specialized setae (mastitarsala) on tarsus of the Leg III in E. batatas (Figure 4F), while there is one in E. alfreddugesi (Figure 5F). The number of idiosomal setae in E. batatas and E. alfreddugesi, is respectively, 58 and 38 , and the chaetotaxy of both species is shown in Figures 4G, 4H, 5G and 5H. 


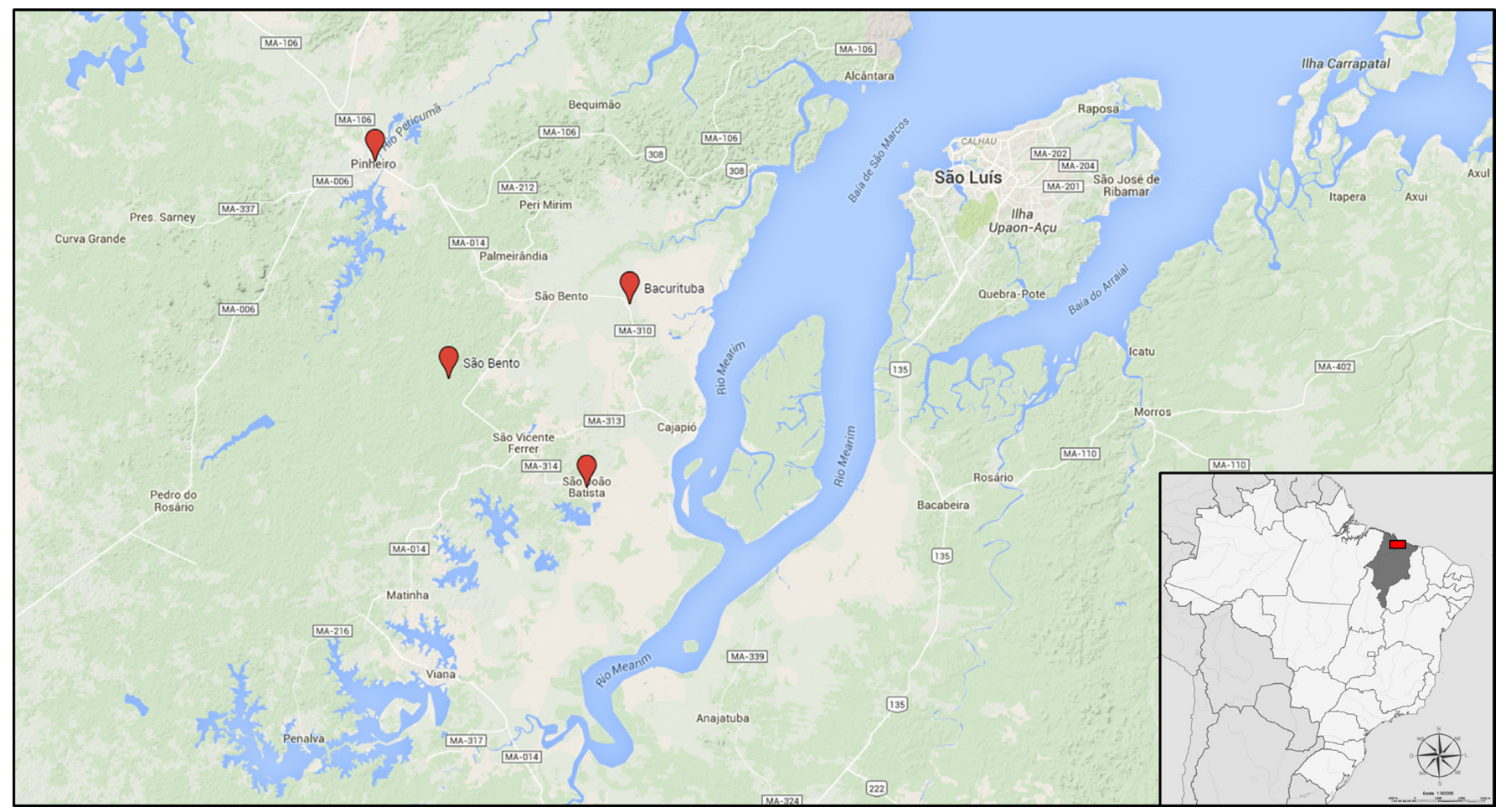

Figure 2. The farms investigated, where chiggers were collected from goats and humans.

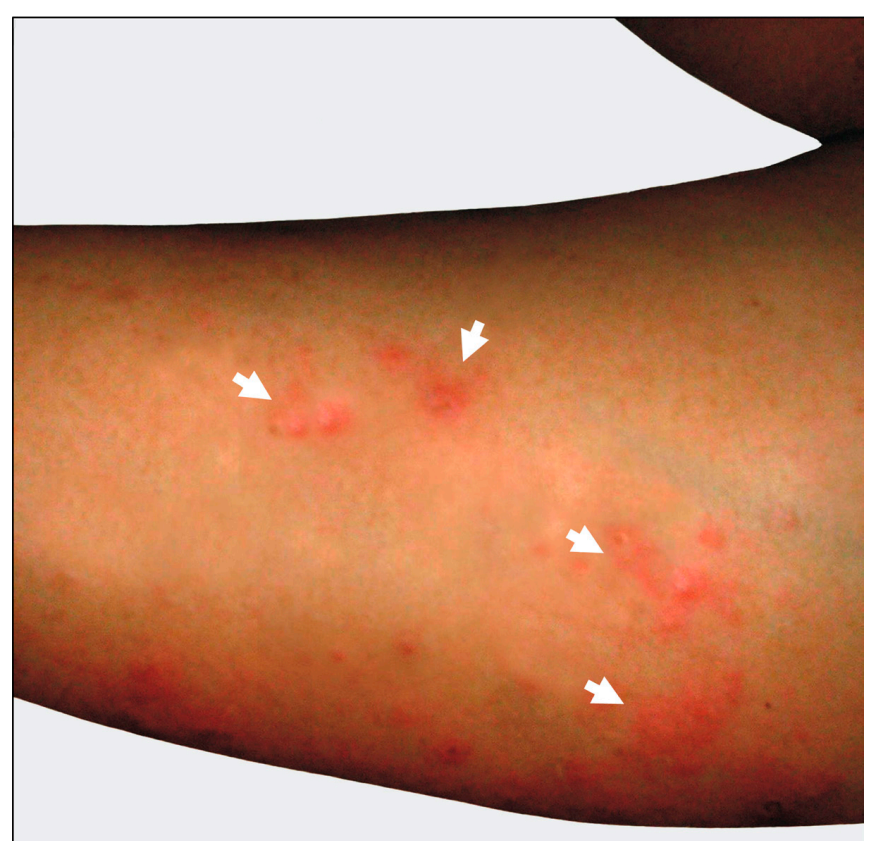

Figure 3. Trombiculiasis: farmer's arm bitten by chiggers (white arrows).

\section{Discussion}

Larvae of Eutrombicula spp. infest a wide range of vertebrates, including mammals, birds, amphibians and reptiles, and have been reported in North America, South America and the Caribbean (HOFFMANN, 1990). In Brazil, E. batatas was reported by Ewing (1925) in Manaus and Carvoeiro cities, state of Amazonas, parasitizing chickens; and in Belém, state of Pará, parasitizing Meleagris gallopavo (Galliformes: Meleagrididae). This species has also been recorded in the state of Mato Grosso, in horses (CONFALONIERI \& BENEZ, 1976) and in Dasyprocta aguti (Rodentia: Dasyproctidae) and humans (JENKINS, 1949). The signs of infestation in both goats and humans in the present study were similar to those that have been described in animals (BAKER, 1999) and humans (CHACCOUR, 2005).

Fonseca (1932a, b) reported the first case of a strong reaction on a leg of a snake handler at the Butantan Institute who was bitten by red chiggers, Trombicula butantanensis Fonseca, 1932 (syn. E. alfreddugesi by JENKINS, 1949). The snakes kept in the Butantan Institute were collected from different Brazilian regions (states of São Paulo or Rio Grande do Sul, and probably also the Correntes river, on the border between the states of Mato Grosso and Mato Grosso do Sul) (FONSECA, 1932b). A Swedish traveler had persistent cutaneous reactions to chigger bites on a trip to the state of Mato Grosso (EITREM \& JAENSON, 2012). Recently, Russian tourists were bitten by chiggers and presented trombiculiasis, when they visited natural areas in the Amazon region of Brazil. They had come into contact with parrots and capybaras (Hydrochoerus hydrochaeris) (BRONSHTEYN et al., 2016) during that trip.

In the present study, there are several factors that may have contributed to the difference in parasitized animals between the two years. It is possible that the humidity, rainfall, temperature and availability of hosts, in those days of collection had been favorable to the high parasitism in the second year. On the other hand, there was not concern to establish a pattern of collections (during wet or dry weather) and mark the infested animals, because the visits to farms were random, once the only concern was to 

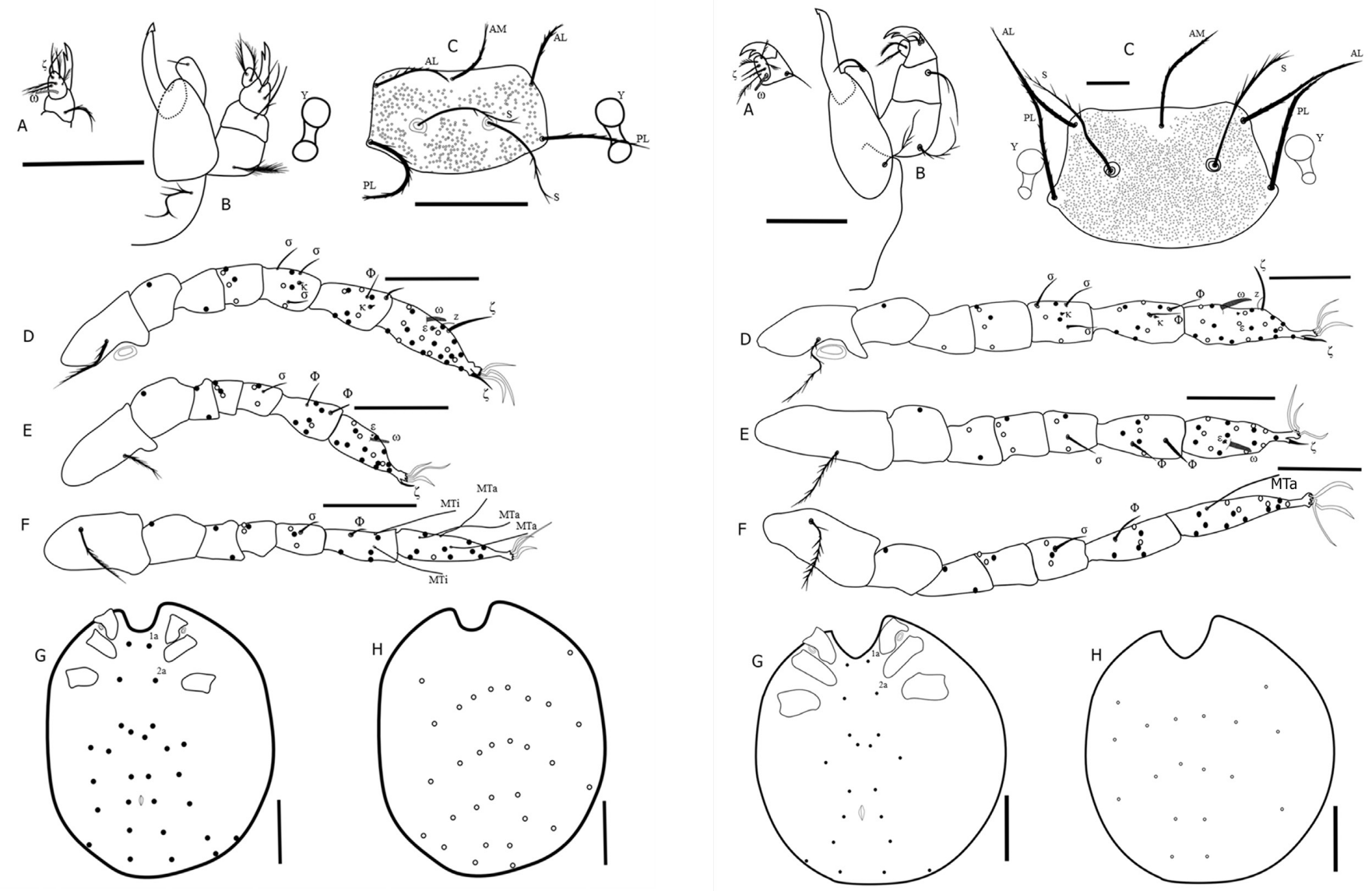

Figure 4. Morphological details of Eutrombicula batatas (Linnaeus). (A) ventral view of palpal tarsus; (B) dorsal view of gnathosoma; (C) scutum; (D) leg I; (E) leg II; (F) leg III; (G) ventral view of idiosoma; $(\mathrm{H})$ dorsal view of idiosoma. The black spots represent the ventral setae, and the white spots represent the dorsal setae. Symbols: $\zeta=$ subterminala of palpal tarsus; $\omega=$ tarsala of palpal tarsus; $\mathrm{AL}=$ anterolateral; $\mathrm{PL}=$ posterolateral; $\mathrm{AM}=$ anteromedial; $\mathrm{S}=$ trichobothria; $\mathrm{Y}=$ eyes; $\sigma=$ sigma I, II and III; $\kappa=$ microsetae on genu and tibia; $\Phi=$ phi I, II and III; $\omega=$ omega I and II; $\varepsilon=$ famulus I and II; $\zeta=$ subterminala I, pretarsala I, II; $z=$ parasubterminala I; $\mathrm{MTa}=$ mastitarsala; $\mathrm{Mti}=$ mastitiabiala; $1 \mathrm{a}=$ anterior sternal setae; $2 \mathrm{a}=$ posterior sternal setae. Scale bars: A, B, D-F $50 \mu \mathrm{m}$; C, G, H $100 \mu \mathrm{m}$.

determine what had caused the lesions as in goats as in humans. The owners of the farms investigated commented that infestations on goats and humans are more common during the rainy season, which lasts from March to September. Most of the domestic goat herds in the state of Maranhão belong to smallholder farms that practice extensive subsistence rearing without proper facilities or regular sanitation procedures. For feeding, the animals are released from handmade rustic corrals into nearby natural forested areas in the mornings and return at dusk. In this scenario, they have unlimited access to the same areas inhabited by the local native fauna that can be the natural hosts for these chiggers. Children probably acquire the chiggers when they go into the forested areas to play or help their parents and adults acquire them through goat management. The result from this interaction consisted of infestation of goats and humans by unfed larvae.

Figure 5. Morphological details of Eutrombicula alfreddugesi (Oudemans). (A) ventral view of palpal tarsus; (B) dorsal view of gnathosoma; (C) scutum; (D) leg I; (E) leg II; (F) leg III; (G) ventral view of idiosoma; $(\mathrm{H})$ dorsal view of idiosoma. The black spots represent the ventral setae, and the white spots represent the dorsal setae. Symbols: $\zeta$ = subterminala of palpal tarsus; $\omega=$ tarsala of palpal tarsus; $\mathrm{AL}=$ anterolateral; $\mathrm{PL}=$ posterolateral; $\mathrm{AM}=$ anteromedial; $S=$ trichobothria; $\mathrm{Y}=$ eyes; $\sigma=$ sigma I, II and III; $\kappa=$ microsetae on genu and tibia; $\Phi=$ phi I, II and III; $\omega=$ omega I and II; $\varepsilon=$ famulus I and II; $\zeta=$ subterminala I, pretarsala I, II; z = parasubterminala I; $\mathrm{MTa}=$ mastitarsala; $1 \mathrm{a}=$ anterior sternal setae; $2 \mathrm{a}=$ posterior sternal setae. Scale bars: A, B, D-F $50 \mu \mathrm{m}$; C $20 \mu \mathrm{m}$; G, H $100 \mu \mathrm{m}$.

The Brazilian Amazon region is a new frontier where agriculturally sustainable development and livestock activities have been attempted over the last few decades. The presence of humans and domestic animals in these recently explored areas might result in new, distinct associations and adaptations of the native parasitic arthropod fauna to the newly integrated hosts, as reported by Labruna et al. (2002) in relation to domestic pigs and ticks.

This is the first record of parasitism by E. alfreddugesi and $E$. batatas on goats, and the second record on humans in Brazil. Trombiculiasis is a neglected parasitic disease in the Neotropics because of difficulty in diagnosing the presence of these mites, and also because of lack of knowledge among healthcare professionals. Thus, this report may serve as a warning to professional medical and 
veterinary services, since chigger mites are known to be potential vectors of pathogens in various regions of the world.

The species E. batatas and E. alfreddugesi were reported as pests in North, Central and South America, and both were found together in the same host. When they are found parasitizing human, they also have been found together (BENNETT \& LOOMIS, 1980; HOFFMANN, 1990), confirming our findings in Maranhão.

Unfortunately, there was not enough material from the chiggers for molecular preparations at this time, but since specimen collection is continuing, material will be available in the near future to acquire molecular sequences from chiggers.

\section{Acknowledgements}

This work was supported in part by a CNPq grant (454907/2014-1) to DMBB. To Ronald Ochoa, curator of the USNM Smithsonian Acari Collection, located at the Systematic Entomology Laboratory (BARC-USDA-ARS), for giving us free access to the largest collection of chiggers in the world. To Debra D. Creel for technical assistance to loaning chigger types and material.

\section{References}

Baker AS. Mites and ticks of domestic animals: an identification guide and information source. London: The Stationary Office; 1999.

Bennett SG, Loomis RB. The tropical pest chigger, Eutrombicula batatas (Acarina: Trombiculidae), in Arizona and California, USA.J Med Entomol 1980; 17(3): 286. http://dx.doi.org/10.1093/jmedent/17.3.286.

Brennan JM, Goff ML. Keys to the genera of chiggers of the western hemisphere (Acarina: Trombiculidae). J Parasitol 1977; 63(3): 554-566. PMid:68115. http://dx.doi.org/10.2307/3280021.

Bronshteyn AM, Kochergin NG, Malyshev NA, Konstantinov OK, Davydova IV, Burova SV. Trombiculiasis in Russian tourists travelled to tropical countries. Epidemiol Infektsionnye Bolezni 2016; 21(1): 43-50.

Carneiro LS. Uma nova acariase humana: continuição ao seu estudo [Thesis]. Recife: Faculdade de Medicina, Universidade de Recife; 1952.

Chaccour CJ. Trombiculiasis: reporte de dos casos y revisión de la literatura. Dermatol Venez 2005; 43(2): 18-21.

Choi YJ, Lee EM, Park JM, Lee KM, Han SH, Kim JK, et al. Molecular detection of various rickettsiae in mites (acari: trombiculidae) in southern Jeolla Province, Korea. Microbiol Immunol 2007; 51(3): 307-312. PMid:17380050. http://dx.doi.org/10.1111/j.1348-0421.2007.tb03912.x.

Confalonieri UEC, Benez EJ. Nota sobre um novo hospedeiro para Eutrombicula (Eutrombicula) batatas (L.) no Brasil (Acari: Trombiculidae). Rev Bras Biol 1976; 36(2): 353-355.

Eitrem R, Jaenson TG. Persistent pruritus caused by tropical chiggers: trip to Brazil caused a phenomenon unknown in Sweden. Lakartidningen 2012; 109(51-52): 2358-2359. PMid:23367551.

Ewing HE. A new chigger (Trombicula larva) from Brazil. Proc Entomol Soc Wash 1925; 27(4): 91-92.

Faccini JLH, Ribeiro VR. Raillietia caprae (Acari: Raillietidae) and Psoroptes ovis (Acari: Psoroptidae) in the ears of goats in the state of Rio de Janeiro, Southeast Brazil. Rev Bras Parasitol Vet 2008; 17(1): 59-61. PMid:18554445. http://dx.doi.org/10.1590/S1984-29612008000100014.
Fernández-Soto P, Pérez-Sánchez R, Encinas-Grandes A. Molecular detection of Ehrlichia phagocytophila genogroup organisms in larvae of Neotrombicula autumnalis (Acari: Trombiculidae) captured in Spain. J Parasitol 2001; 87(6): 1482-1483. PMid:11780844. http://dx.doi. org/10.1645/0022-3395(2001)087[1482:MDOEPG]2.0.CO;2.

Fonseca F. Notas de Acareologia V. Trombicula butantanensis sp. n. (Acarina, Trombidiidae). Mem Inst Butantan 1932a; 7: 148-150.

Fonseca F. Notas de Acareologia VI. Duas novas espécies de larvas do genero Trombicula: Trombicula ophidica, sp. n. e Trombicula ewingi, sp. n. (Acarina, Trombidiidae); nota sobre Trombicula butantanensis Fl. da Fonseca, 1932 e sobre a inexistencia de T. akamushi (Brumpt, 1910) entre nós. Mem Inst Butantan 1932b; 7: 151-158.

Guimarães JH, Tucci EC, Barros-Battesti DM. Ectoparasitos de importância veterinária. São Paulo: Plêiade; 2001.

Hoffmann A. Los trombiculideos de Mexico (Acarida: Trombiculidae). Ciudad del Mexico: Universidade Nacional Autonoma de Mexico; 1990.

Jenkins DW. Trombiculid mites affecting man. IV. Revision of Eutrombicula in the American Hemisphere. Ann Entomol Soc Am 1949; 42(3): 289318. http://dx.doi.org/10.1093/aesa/42.3.289.

Jones BM. The penetration of the host tissue by the harvest mite, Trombicula autumnalis Shaw. Parasitology 1950; 40(3-4): 247-260. PMid:14785964. http://dx.doi.org/10.1017/S0031182000018096.

Kampen H, Schöler A, Metzen M, Oehme R, Hartelt K, Kimmig P, et al. Neotrombicula autumnalis (Acari, Trombiculidae) as a vector for Borrelia burgdorferi sensu lato? Exp Appl Acarol 2004; 33(1-2): 93-102. PMid:15285141. http://dx.doi.org/10.1023/B:APPA.0000029975.92510.90.

Labruna MB, Camargo LM, Schumaker TT, Camargo EP. Parasitism of domestic swine (Sus scrofa) by Amblyomma ticks (Acari: Ixodidae) on a farm at Monte Negro, western Amazon, Brazil. J Med Entomol 2002; 39(1): 241-243. PMid:11931265. http://dx.doi.org/10.1603/00222585-39.1.241.

Literak I, Stekolnikov AA, Sychra O, Dubska L, Taragelova V. Larvae of chigger mites Neotrombicula spp. (Acari: Trombiculidae) exhibited Borrelia but no Anaplasma infections: a field study including birds from the Czech Carpathians as hosts of chiggers. Exp Appl Acarol 2008; 44(4): 307-314. PMid:18401688. http://dx.doi.org/10.1007/s10493-008-9150-1.

Loomis RB, Wrenn WJ. Systematics of the pest chigger genus Eutrombicula (Acari: Trombiculidae). In: Griffiths DA, Bowman CE. Acarology VI. Great Britain: Ellis Horwood Publishers; 1984. p. 152-159.

Ornelas-Almeida MA, Oliveira FRB, Silva AE, Moreira ELT, Maia PCC, Duarte LFC, et al. Nodular trombiculinosis caused by Apolonia tigipioensis, Torres and Braga (1938), in an ostrich (Struthio camelus) and a house sparrow (Passer domesticus). Vet Parasitol 2007; 150(4): 374-377. PMid:17981395. http://dx.doi.org/10.1016/j.vetpar.2007.09.020.

Padilha TN. Doenças parasitárias em caprinos nas regiōes áridas e semi-áridas do nordeste brasileiro. Pernambuco: EMBRAPA; 1982.

Shatrov AB. Trombiculid mites and their parasitism on vertebrate hosts. Saint Petersburg: Saint Petersburg University Publishers; 2000.

Takahashi M, Misumi H, Urakami H, Nakajima S, Furui S, Yamamoto $S$, et al. Mite vectors (Acari: Trombiculidae) of scrub typhus in a new endemic area in northern Kyoto, Japan. JMed Entomol 2004; 41(1): $107-$ 114. PMid:14989353. http://dx.doi.org/10.1603/0022-2585-41.1.107.

Wall R, Kolbe K. Taxonomic priority in Psoroptes mange mites: P. ovis or P. equi? Exp Appl Acarol 2006; 39(2): 159-162. PMid:16733788. http:// dx.doi.org/10.1007/s10493-006-9000-y. 
Walter DE, Krantz GW. Collecting, rearing, and preparing specimens. In: Krantz GW, Walter DE. A Manual of Acarology. 3rd ed. Lubbock: Tech University Press; 2009. p. 83-96.

Wolfenbarger KA. Systematic and biological studies on North American chiggers of the genus Trombicula, subgenus Eutrombicula (Acarina,
Trombiculidae). Ann Entomol Soc Am 1952; 45(4): 645-677. http:// dx.doi.org/10.1093/aesa/45.4.645.

Wrenn WJ, Loomis RB. Host selectivity in the genus Eutrombicula (Acari: Trombiculidae). In: Griffiths DA, Bowman CE. Acarology VI. Great Britain: Ellis Horwood Publishers; 1984. p. 160-165. 